\title{
A Method for Measuring Chemotaxis and Use of the Method to Determine Optimum Conditions for Chemotaxis by Escherichia coli
}

\author{
By J. ADLER \\ Departments of Biochemistry and Genetics, College of Agricultural and Life Sciences, \\ University of Wisconsin, Madison, Wisconsin, 53706, U.S.A.
}

(Received 5 June 1972; revised 15 August I972)

\begin{abstract}
SUMMARY
Chemotaxis of a bacterium such as Escherichia coli is assayed by measuring the number of organisms attracted into a capillary tube containing an attractant. Rate of bacterial accumulation in capillaries and a concentration-response curve for L-aspartate taxis are presented and interpreted, and the effect of bacterial concentration is reported. Other parameters of the assay were studied, such as the volume of fluid in the capillary and the size of the capillary opening. The concentration gradient of chemical was also described. Escherichia coli chemotaxis requires EDTA to allow motility, a buffer to maintain the $\mathrm{pH}$ at its optimum near neutrality, and L-methionine if it cannot be synthesized. Under certain conditions there is stimulation by inorganic ions, either by $\mathrm{K}^{+}$or, less effectively, by $\mathrm{Na}^{+}$. Chemotaxis is dependent on temperature, there being a 20 -fold increase in the number of bacteria accumulating in a capillary when the temperature is raised from 20 to $30{ }^{\circ} \mathrm{C}$.
\end{abstract}

\section{INTRODUCTION}

Motile organisms are attracted by certain chemicals and repelled by others - positive and negative chemotaxis. Until now, bacterial chemotaxis has been assayed in a mainly qualitative and subjective manner. This paper describes an objective method of measuring positive chemotaxis in bacteria and reports the effect of various parameters on this assay.

The basis of this chemotaxis assay is a procedure that Pfeffer developed nearly a century ago ( 1884,1888$)$. He studied chemotaxis by placing a capillary containing a solution of attractant into a suspension of motile bacteria and observing microscopically that the bacteria accumulated around the mouth of the capillary and, later, also inside. This procedure has now been made quantitative by measuring how many bacteria accumulate inside the capillary, and may be referred to as the 'quantitative Pfeffer method' for measuring chemotaxis. The method has been described briefly in our earlier reports (Adler, 1969; Hazelbauer, Mesibov \& Adler, 1969).

Up to the time of this work, bacterial chemotaxis was studied in complex media, such as tryptone, peptone, or meat extract; conditions for obtaining motility and chemotaxis in defined media were not known. In order to identify attractants, as well as for other reasons, it was first necessary to determine the conditions, chemical and otherwise, needed for optimum motility and chemotaxis. A report on requirements for motility has already been presented (Adler \& Templeton, 1967). The requirements for chemotaxis are described in this paper. 


\section{METHODS}

Media and chemicals. Medium contained (/l distilled water) $5 \mathrm{~g}$ glycerol (separately autoclaved) and the following salts (Kaiser \& Hogness, I960): $\mathrm{K}_{2} \mathrm{HPO}_{4}$, I I $2 \mathrm{~g} ; \mathrm{KH}_{2} \mathrm{PO}_{4}, 4.8 \mathrm{~g}$; $\left(\mathrm{NH}_{4}\right)_{2} \mathrm{SO}_{4}, 2.0 \mathrm{~g} ; \mathrm{MgSO}_{4} .7 \mathrm{H}_{2} \mathrm{O}, 0.25 \mathrm{~g}$; and $\mathrm{Fe}_{2}\left(\mathrm{SO}_{4}\right)_{3}, 0.5 \mathrm{mg}$. For a galactose-salts medium the glycerol was replaced by D-galactose. Tryptone broth consisted of $\mathrm{I} \%$ tryptone (Difco) and $0.5 \% \mathrm{NaCl}$. Tryptone agar and soft tryptone agar contained in addition agar (Difco) at $\mathrm{I} .5 \%$ and $0.7 \%$, respectively. Medium for stabs contained $0.8 \%$ nutrient broth, $0.1 \%$ yeast extract, and $0.75 \%$ agar (all Difco).

Wash medium contained: potassium phosphate buffer $(\mathrm{pH} 7 \cdot 0), \mathrm{IO}^{-2} \mathrm{M} ; \mathrm{MgSO}_{4}, \mathrm{IO}^{-3}{ }_{\mathbf{M}} \mathrm{M}$; and potassium ethylenediaminetetraacetate (EDTA), $\mathrm{IO}^{-4} \mathrm{M} .\left(\mathrm{MgSO}_{4}\right.$ has subsequently been omitted; see Results.) Chemotaxis medium contained: potassium phosphate buffer ( $\mathrm{pH}$ 7.0), $\mathrm{IO}^{-2} \mathrm{M}$; potassium EDTA, $10^{-4} \mathrm{M}$; and L-methionine, $10^{-6} \mathrm{M}$. (Methionine has subsequently been omitted except for methionine auxotrophs or prototrophs grown in the presence of methionine; see Results.) The wash and chemotaxis media, as well as all other solutions used in the chemotaxis assay, were prepared with glass-distilled water. Organic reagents used in the chemotaxis assay were sterilized by filtration. EDTA, aspartic acid, and $\alpha$-methylaspartic acid were neutralized with $\mathrm{KOH}$. Amino acids were of the L-configuration except for DL- $\alpha$-methylaspartic acid, and sugars were of the D-configuration, except for L-arabinose.

Bacteria. The organism used in this work (unless otherwise mentioned) was Escherichia coli K-I 2 strain BI4 (from Dr J. Lederberg, Stanford University, Palo Alto, California, U.S.A.). This strain was previously referred to as w3I ro made streptomycin-resistant (Adler, 1969). However, w3IIO is $\mathrm{F}^{-}$, but BI4 is sensitive to the male-specific phages $\mathrm{GI}_{7} 7$ and MS2 and can transfer genetic markers to $\mathrm{F}^{-}$strains $(\mathrm{E}$. N. Kort, personal communication). Hence, the relationship of BI 4 to $\mathrm{W}_{3} \mathrm{I}$ IO is uncertain; most likely BI 4 is a close relative of the $\mathrm{F}^{+}$parent of w3IIO, WI485.

The properties and origin of Escherichia coli $\mathrm{K}-\mathrm{I} 2$ strain $20 \mathrm{SOK}^{-}$, which is defective in both transport and metabolism of galactose, have been described previously (Adler, 1969). Escherichia coli strain 2-46, a methionine auxotroph (met F), was isolated by E. N. Kort from AW405 (Hazelbauer et al. 1969).

Strains were maintained in nutrient broth + yeast extract agar stabs at $4{ }^{\circ} \mathrm{C}$. Motile strains were re-isolated yearly by allowing them to swarm on a semisolid tryptone agar plate (Adler, 1966) and then picking from the edge of the swarm.

Bacteria, from a stab, were grown to stationary phase (overnight) in tryptone broth (I $\mathrm{ml}$ in a $\mathrm{I} 25 \mathrm{ml}$ flask) at $35^{\circ} \mathrm{C}$ with rotatory shaking (I00 to $250 \mathrm{rev} . / \mathrm{min}$ ). Such cultures, kept at $4{ }^{\circ} \mathrm{C}$, were used for up to three weeks. Bacteria from the tryptone broth culture ( $0 . \mathrm{I} \mathrm{ml}$ ) were adapted to glycerol-salts medium ( $10 \mathrm{ml}$ in a $125 \mathrm{ml}$ flask) by growth to stationary phase (overnight) at $35^{\circ} \mathrm{C}$ with rotatory shaking. Without shaking, the bacteria were poorly motile. Such cultures were stored at $4{ }^{\circ} \mathrm{C}$ and were used for up to one week.

For each day's experiment, bacteria from glycerol-salts medium were inoculated into $10 \mathrm{ml}$ of glycerol-salts medium in a $125 \mathrm{ml}$ flask to give an initial extinction at $590 \mathrm{~nm}$ in a I cm cuvette of about 0.05 , and then incubated as described above until the extinction reached 0.2 to 0.4 . (An extinction at $590 \mathrm{~nm}$ of $\mathrm{I} \cdot 0=6 \times 10^{8}$ bacteria $/ \mathrm{ml}$; growth becomes exponential at an extinction of $0 \cdot 1$ and ceases to be exponential at about $2 \cdot 0$.)

About $6 \times 10^{8}$ bacteria were centrifuged for $10 \mathrm{~min}$ at $8000 \mathrm{~g}$ at $4{ }^{\circ} \mathrm{C}$. The supernatant solution was decanted and the pellet was gently resuspended by slowly shaking or rocking by hand before adding $5 \mathrm{ml}$ of wash medium (see Media and chemicals above). The bacteria were again centrifuged, resuspended as before in $5 \mathrm{ml}$ of wash medium, and recentrifuged. 


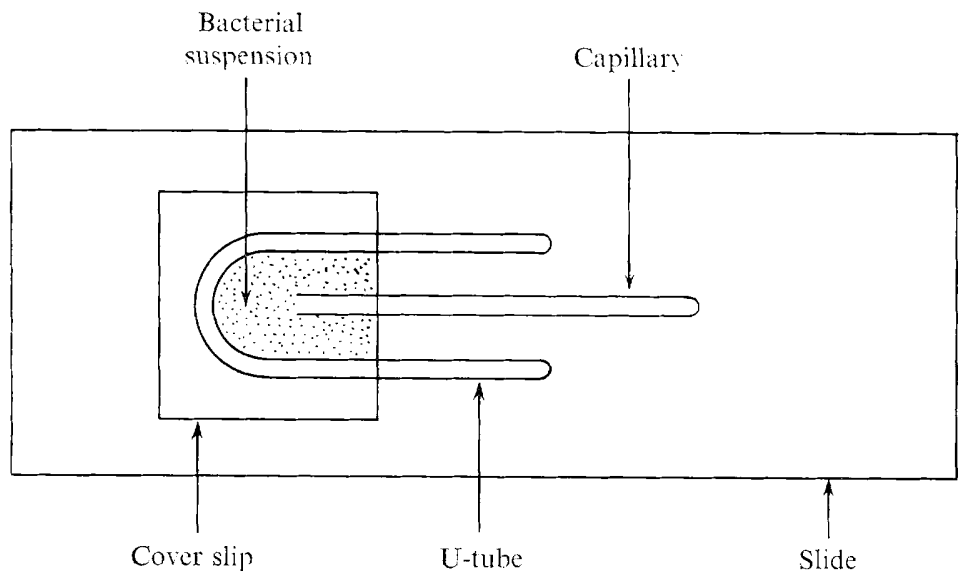

Fig. I. Apparatus used in the chemotaxis assay. The drawing is to scale except that the width of the capillary is exaggerated.

The final pellet was gently resuspended without addition of any liquid. More than $90 \%$ of the bacteria were very motile, as judged by microscopic observation. After three additional washes, the motility was still good, so this washing procedure is safe for preserving the motility. However, some strains of Escherichia coli when washed at $4{ }^{\circ} \mathrm{C}$ lost motility (G. W. Ordal \& R. W. Reader, personal communication). In these cases, centrifuging was at room temperature at $3400 \mathrm{~g}$ for $10 \mathrm{~min}$. Perhaps centrifuging at room temperature should be recommended for routine use.

To the resuspended pellet was added up to $10 \mathrm{ml}$ of chemotaxis medium (see Media and chemicals above) to bring the bacterial concentration to $6 \times 10^{7}$ per $\mathrm{ml}$. This suspension could be stored at $4{ }^{\circ} \mathrm{C}$ for at least $2 \mathrm{~h}$, and at $30{ }^{\circ} \mathrm{C}$ for at least $\mathrm{I} \cdot 5 \mathrm{~h}$, without loss of chemotactic ability.

Chemotaxis assay. A small chamber was formed by laying a $\mathrm{U}$-shaped tube (bent from a $5 \mathrm{~cm}$ length of melting point capillary tube, Kimax, no. 34502, obtained from Kimble Products, Owens-Illinois, Toledo, Ohio, U.S.A., and then sealed at both ends) between a microscope slide and a cover slip (Fig. I). This setup was held at $30^{\circ} \mathrm{C}$, unless otherwise mentioned, on a slide warmer (Fisher Scientific Co., Pittsburgh, Pennsylvania, U.S.A.). (As many as 48 assays can be conveniently carried out at one time on one slide warmer; for such large numbers of assays it was more convenient to replace the microscope slides with a glass plate that covers the available area of the slide warmer.) The chamber was then filled with about $0.2 \mathrm{ml}$ of the above bacterial suspension. (This chamber can be replaced by a Lexy culture chamber, obtained from Mini-Lab, Laval, Quebec, Canada, but we have found that responses are only $\frac{1}{2}$ to $\frac{1}{8}$ as great as with our standard setup.)

The capillary tubes for containing the attractant were I $\mu$ l disposable micropipettes, $3 \mathrm{~cm}$ long with an internal diameter of $0.2 \mathrm{~mm}$ ('Microcaps', from Drummond Scientific Co., Broomall, Pennsylvania, U.S.A.). The capillaries were handled with forceps. One end was sealed in a flame; the capillary was then quickly passed several times through the flame and immediately plunged open end down into a $\mathrm{I} 0 \mathrm{ml}$ beaker containing about $\mathrm{I} \mathrm{ml}$ of attractant dissolved in chemotaxis medium. As the capillary cooled, liquid was drawn in about $\mathrm{I} \mathrm{cm}$. After about to min, the capillary was then inserted (without rinsing) open end first into the chamber containing the bacterial suspension (Fig. I). 


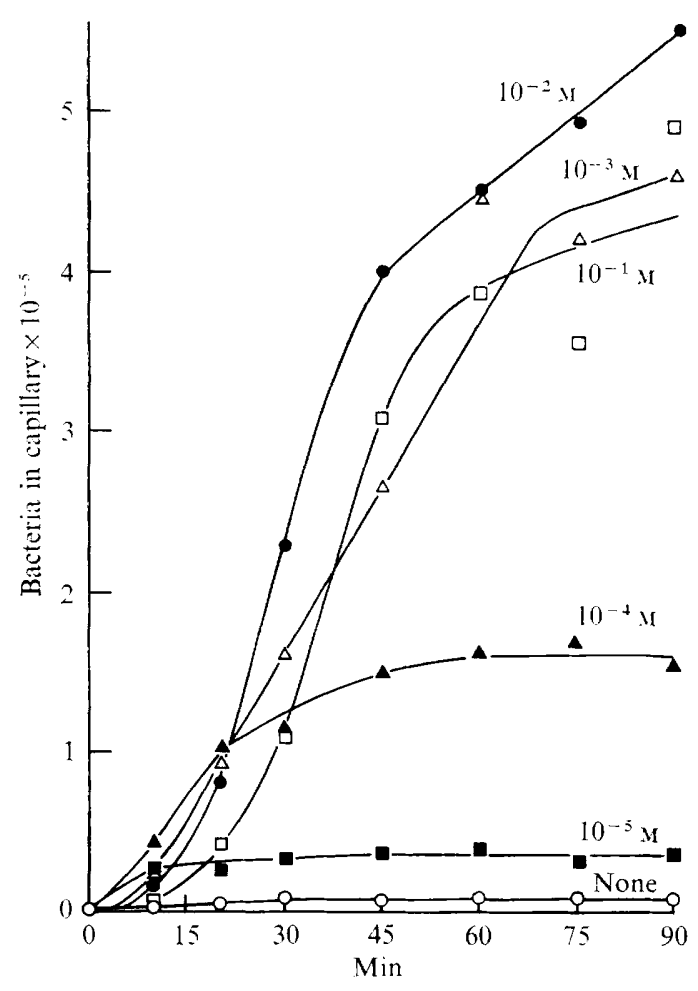

Fig. 2. Rate of accumulation of bacteria in capillaries containing various concentrations of Laspartate. $\bigcirc-O$, No aspartate; $-\square, 10^{-5} \mathrm{M} ; \Delta-\Delta, 10^{-4} \mathrm{M} ; \Delta \longrightarrow-\Delta, \quad 10^{-3} \mathrm{M}$; $-10^{-2} \mathrm{M} ; \square-\square, 10^{-1} \mathrm{M}$. Data from two experiments were combined. The experiments were carried out at $30^{\circ} \mathrm{C}$.

After incubation for $\mathrm{I} h$, unless otherwise mentioned, the capillary was removed. Its exterior was rinsed with a thin stream of water from a wash bottle, the sealed end was broken off over (to catch any droplets) a test tube containing tryptone broth at $0{ }^{\circ} \mathrm{C}$, and the contents were squirted into the tryptone broth with the aid of a rubber bulb supplied with the micropipettes. Suitable dilutions were made in tryptone broth, and then a sample was mixed with $2 \mathrm{ml}$ of soft tryptone agar at $45^{\circ} \mathrm{C}$ and poured on a tryptone agar plate, which has a higher plating efficiency than eosin-methylene blue glucose plates which were used previously (Adler, 1969). After incubation overnight at $37{ }^{\circ} \mathrm{C}$, colonies were counted. Assay points were duplicates for all experiments reported here. Averages are reported; in these experiments the maximum range from the average was $27 \%$.

\section{RESULTS}

Rates of accumulation. Fig. 2 shows the rates of accumulation of bacteria in capillaries. When the capillary contained no attractant (bottom curve), a relatively small number of bacteria entered the capillary: after $90 \mathrm{~min}$ only I 000 bacteria were found inside. This 'background' accumulation occurs presumably by random swimming; with a non-motile strain only 100 bacteria were found in the capillary at $60 \mathrm{~min}$. When the capillary contained L-aspartate, motile bacteria were attracted, after a lag period, into the capillary at a more or less constant rate until a decline in rate or a plateau was reached. With $\mathrm{IO}^{-1}, \mathrm{rO}^{-2}, \mathrm{IO}^{-3}$, 
$\mathrm{IO}^{-4}$, or $\mathrm{IO}^{-5} \mathrm{M}$-aspartate, the lags were about $\mathrm{IO}, 6,4, \mathrm{I}$, and o min, respectively; the maximal rates were $8 \cdot 0,8 \cdot 5,4 \cdot 0,3 \cdot 0$, and $\mathrm{I} \cdot 6 \times 10^{5}$ bacteria/h, respectively; and for $10^{-1}, \mathrm{IO}^{-2}$, and $10^{-3} \mathrm{M}$ the rates declined from 45 to $60 \mathrm{~min}$, while a plateau was reachedat $60 \mathrm{~min}$ for $10^{-4} \mathrm{M}$ and at $10 \mathrm{~min}$ for $10^{-5} \mathrm{M}$. For different attractants, the kinetics do not necessarily resemble those shown in Fig. 2 (see Discussion).

With $1 \mathrm{I}^{-2}$ or $1 \mathrm{O}^{-3} \mathrm{M}$-aspartate as an attractant, a cloud of bacteria, $\mathrm{I}$ to $2 \mathrm{~mm}$ in diameter, formed at the mouth of the capillary by $20 \mathrm{~min}$ and was visible to the naked eye in bright light.

In the above experiments the initial concentration of bacteria was $6 \times 10^{7}$ per $\mathrm{ml}$, i.e. $\mathrm{I} \cdot 2 \times 10^{7}$ bacteria in the $0.2 \mathrm{ml}$ used. The largest number of bacteria attracted into a capillary in one hour in any such experiment we have carried out is $8 \times 10^{5}$ and was with $3 \times 10^{-3} \mathrm{M}-$ aspartate at $30{ }^{\circ} \mathrm{C}$. This represents $7 \%$ of the bacteria added.

Although an hour has been adopted as the standard time for incubation in the work reported in this paper, 30 or $45 \mathrm{~min}$ should be used in future work as the rates of accumulation tend to fall off before $60 \mathrm{~min}$.

Accumulation of bacteria in the capillary tubes cannot be explained by bacteria being carried in passively by convection, since (i) the bacteria have to be motile in order to accumulate in the capillaries; (ii) motile but non-chemotactic mutants (Adler, 1969) show no increased accumulation in capillaries containing attractants; (iii) an attractant must be present in the capillary (Fig. 2, bottom curve); (iv) if attractant is present in both the capillary and bacterial suspension at equal concentration, there is no accumulation above the background; and (v) some chemicals in the capillaries cause accumulation of bacteria there, while other closely related ones do not, for example, L-aspartate does and L- $\alpha$-aminoadipate does not.

Concentration-response curves. The $\mathrm{I}-\mathrm{h}$ responses to different concentrations of aspartate (Fig. 3) are consistent with the I-h data shown in Fig. 2. Concentration-response curves resembling that of Fig. 3 have been obtained for a large number of amino acids and sugars (Adler, 1969; unpublished results). The 'threshold concentration', the lowest concentration of attractant that gives an accumulation in the capillary greater than that obtained in the absence of attractant, is about $10^{-6} \mathrm{M}$ with aspartate (see Fig. 3), though if the bacterial concentration is lowered by I00-fold to avoid significant losses of the attractant by metabolism, the threshold for aspartate drops to $3 \times 10^{-8} \mathrm{M}$. The threshold $\left(\mathrm{IO}^{-6} \mathrm{M}\right)$ for a non-metabolizable attractant, $\alpha$-methylaspartate, is not affected by diluting the bacteria. Alternatively, a strain of bacteria that can neither metabolize nor transport the attractant can be used to determine precise thresholds. For example, at the usual bacterial concentration, $6 \times 10^{7}$ per $\mathrm{ml}$, the threshold for galactose is about $10^{-6} \mathrm{M}$ for wild-type Escherichia coli strains such as $\mathrm{BI} 4$, but is about $\mathrm{IO}^{-8} \mathrm{M}$ for E. coli $20 \mathrm{SOK}^{-}$, which cannot transport or metabolize galactose (Adler, I969).

The 'peak concentration', where the maximum response to attractant occurs, is at $10^{-2} \mathrm{M}$ for aspartate (Fig. 3) but will depend on the time of incubation (see Fig. 2), and also on the utilization of the attractant by the bacteria. Thus, when the bacterial concentration was lowered I00-fold the peak shifted to $10^{-3} \mathrm{M}$-aspartate. The peak for galactose occurred at $\mathrm{IO}^{-3} \mathrm{M}$ with strain $\mathrm{BI} 4$ but at $\mathrm{IO}^{-5} \mathrm{M}$ with strain $20 \mathrm{SOK}^{-}$in a $\mathrm{I}-\mathrm{h}$ experiment at the usual bacterial concentration (Adler, 1969).

Explanations for the decreased response at the highest concentrations (Fig. 3) will be suggested in the Discussion.

Effect of bacterial concentration. Without attractant in the capillary (bottom curve, Fig. 4), the number of bacteria accumulating was directly proportional to the initial concentration 


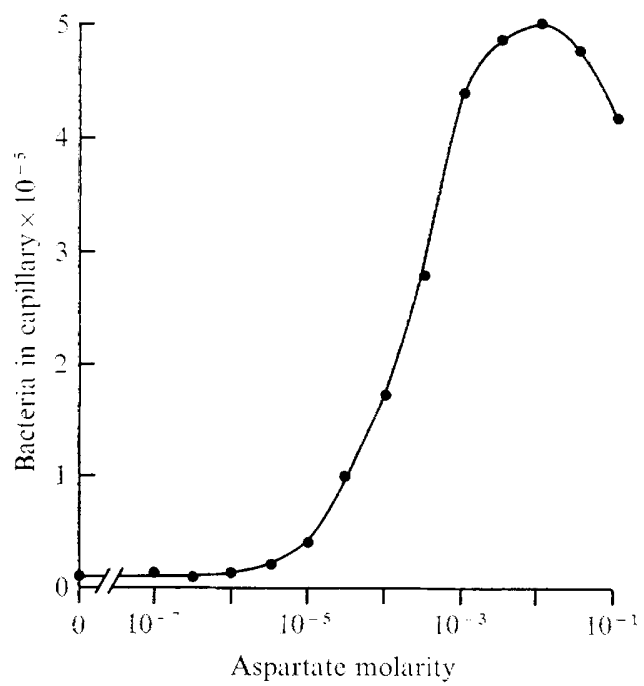

Fig. 3. Concentration-response curve for L-aspartate. The concentration of aspartate in the capillary is plotted on the abscissa. The experiment was carried out at $30^{\circ} \mathrm{C}$ for $\mathrm{I} h$.

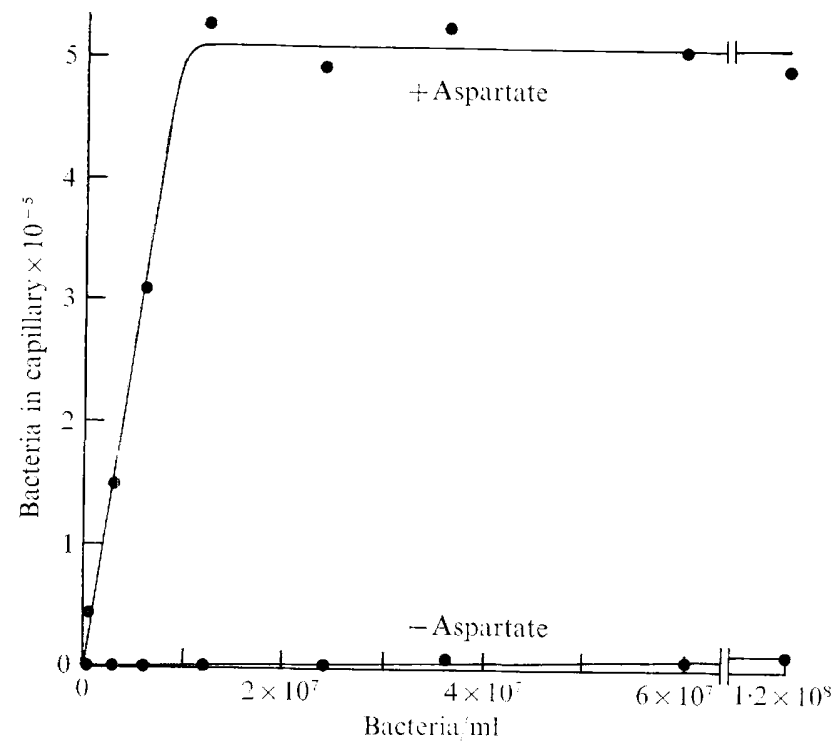

Fig. 4. Effect of bacterial concentration. The number of bacteria that had accumulated in the capillary at $\mathrm{I} h$ is plotted against the concentration of bacteria outside the capillary initially. The experiment was carried out at $30^{\circ} \mathrm{C}$ and L-aspartate, when present (top curve), was at $10^{-3} \mathrm{M}$. A bacterial concentration of $6 \times 10^{8} / \mathrm{ml}$ corresponds to an extinction at $590 \mathrm{~nm}$ of $\mathrm{I} \cdot 0$.

of bacteria over the range studied. With $\mathrm{I}^{-3} \mathrm{M}$-aspartate in the capillary (top curve, Fig. 4), the number of bacteria accumulating was directly proportional to the concentration of bacteria up to $\mathrm{I} \times \mathrm{IO}^{7}$ per $\mathrm{ml}$ (the 'linear portion'), then a plateau $\left(5 \cdot \mathrm{I} \times \mathrm{IO}^{5}\right.$ bacteria/h) was reached. For the linear portion of the curve, the ratio of accumulation in the presence of attractant to accumulation in its absence, was $450: 1$. Of the bacteria added $25 \%$ had accumulated in the capillary at $\mathrm{I} h$. 
With other attractants the bacterial concentration at which the plateau was reached and also the extent of the accumulation at plateau was different from that for aspartate (results not shown).

The reason for the plateau is not clear, and may be different for different attractants. At various bacterial concentrations on the plateau for aspartate (Fig. 4), $\left(\mathrm{I} \cdot 2 \times 10^{7}, 6 \times 10^{7}\right.$, and $1.2 \times 10^{8}$ bacteria/ml) accumulations in capillaries were linear up to $60 \mathrm{~min}$ and were nearly identical in each case. Some unknown factors probably become limiting at high bacterial concentrations. Orifice size of the capillary is a possible factor for the attractants that give the highest plateau values. Indeed, accumulations are greater if capillaries with larger openings are used (see below). Another reason for a plateau comes from the observation of Berg \& Brown (1972) that the cloud of bacteria which accumulates near the mouth of the capillary sinks, and that this does not occur at low bacterial densities where clouds are less populated.

For most purposes, working on the linear portion of the curve is recommended. (The experiments reported in this paper were all carried out on the plateau portion, at a bacterial concentration of $6 \times 10^{7}$ per $\mathrm{ml}$, before these data were available.) First, this provides the maximum ratio, accumulation in the presence of attractant to accumulation in its absence. Secondly, this portion should be most sensitive to the chemotactic ability of the organisms; in the plateau region chemotaxis may not be the limiting step. Although the bacterial concentration that gives linearity needs to be determined for each attractant and each bacterial strain, perhaps the concentration range from 3 to $6 \times 10^{6}$ bacteria $/ \mathrm{ml}$ (an extinction at $590 \mathrm{~nm}$ of 0.005 to $0.0 \mathrm{I}$ ) can be suggested as generally satisfactory. Reproducibility suffers considerably at lower bacterial concentrations (see Reproducibility below), and this is particularly serious with relatively poor attractants. In the case of attractants that can be transported and metabolized, using the lowest possible bacterial concentration is recommended when alteration of the attractant gradient by the bacteria is to be avoided.

Reproducibility. In one experiment 20 capillaries were used to measure the response to $\mathrm{IO}^{-3} \mathrm{M}$-aspartate in $\mathrm{I} h$ at $30{ }^{\circ} \mathrm{C}$ at the usual bacterial concentration of $6 \times \mathrm{IO}^{7} / \mathrm{ml}$. The range accumulating was $4.2 \times 10^{5}$ to $6.0 \times 10^{5}$ bacteria, with a mean of $5.1 \times 10^{5}$. The standard deviation was $9 \%$. The same experiment carried out at a bacterial concentration of $6 \times 10^{5} / \mathrm{ml}$ gave a range of $2.9 \times 10^{4}$ to $5.8 \times 10^{4}$ bacteria, a mean of $4.4 \times 10^{4}$, and a standard deviation of $18 \%$.

To estimate day-to-day reproducibility, one experiment was repeated on 25 different days. The results ranged between $2.5 \times 10^{5}$ and $5.5 \times 10^{5}$ bacteria attracted into capillaries containing $10^{-2} \mathrm{M}-\mathrm{L}$-glutamate in $45 \mathrm{~min}$ at $30^{\circ} \mathrm{C}$ and the usual bacterial concentration; the mean was $4.0 \times 10^{5}$ bacteria and the standard deviation was $17 \%$ (Mesibov, 1970).

Effect of volume of fluid in the capillary. The length of the column of fluid in I $\mu 1$ micropipettes was varied over the range 0.5 to $2 \mathrm{Imm}$ by varying the amount of heating of the capillary before inserting it into the solution of attractant. At $1.5 \mathrm{~mm}$ and above, all values for bacteria attracted into the capillary were identical within experimental error. Below I $5 \mathrm{~mm}$ smaller values were obtained.

Effect of capillary diameter. Experiments were carried out with micropipettes of $1,2,3$, 4,5 and Io $\mu \mathrm{l}$ size having internal diameters of $0.20,0.28,0.35,0.40,0.45$ and $0.56 \mathrm{~mm}$ respectively (measurements provided by the supplier). With the $\mathrm{I}, 2,3,4,5$ and $10 \mu 1$ micropipettes, respectively, $63,63,36,25,13$ and 23 times as many bacteria accumulated in the presence of aspartate compared to in its absence. On this basis, I or $2 \mu 1$ micropipettes are recommended. Diffusion must be more rapid from the wider capillaries and therefore concentration gradients must have been diminished. 


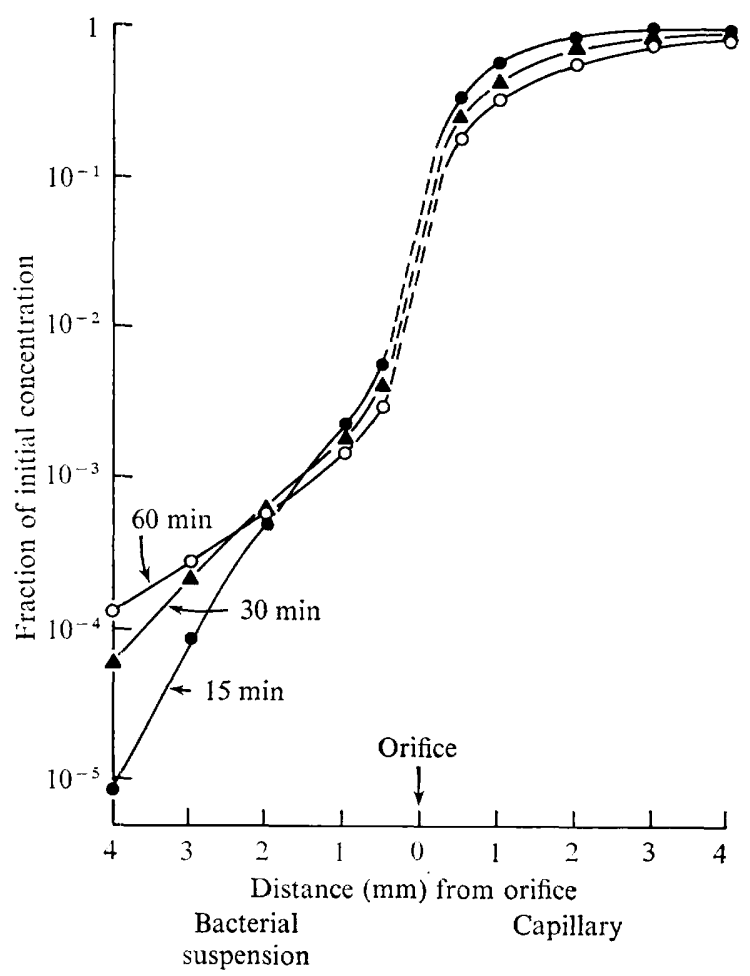

Fig. 5. Gradient of an attractant. These are theoretical curves calculated by Dr H. C. Berg from an equation of Futrelle \& Berg (1972). The fraction of concentration initially present in the capillary

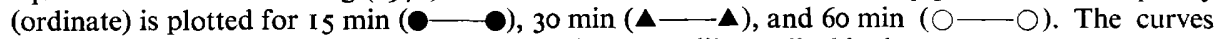
near the orifice are dashed because the theory is not readily applicable there.

The concentration gradient. Futrelle \& Berg (1972) have derived an equation to calculate the concentration of attractant at each point in space and time in an apparatus similar to ours, and have proved the validity of their theory experimentally. Dr Berg has kindly provided numbers calculated from their equation to allow us to describe the concentration gradient at $30^{\circ}$ for an amino acid of molecular weight about 100 . These numbers are plotted in Fig. 5. By I 5 min a steep gradient has already been set up that does not change greatly up to $60 \mathrm{~min}$.

To test the validity of this theoretical result for our experimental conditions, a capillary was filled with $\mathrm{IO}^{-2} \mathrm{M}$-methylene blue in the standard setup without bacteria being added and photographs were taken at various times, and the negatives scanned. Internal standards allowed making a relationship between concentration of dye and the density shown on the scans. Only data for outside the capillary were collected; there was no correction for the fact that the concentrations there were not uniform vertically. The experimental results (data not shown) agreed with those of Fig. 5 within a factor of two.

\section{Use of assay to determine optimum conditions for chemotaxis}

Requirements for motility. Conditions needed for optimum motility in Escherichia coli have been previously summarized (Adler \& Templeton, 1967): (i) a chelating agent, such as EDTA, should be added, since even re-distilled water can contain traces of heavy metal ions, which inhibit motility; (ii) a buffer to keep the $\mathrm{pH}$ at the optimum between 6 and 9 
Table I. Effect of varying the components of the chemotaxis medium

The complete system contained $10^{-2} \mathrm{M}$-potassium phosphate, $\mathrm{pH} 7 \cdot 0,10^{-4} \mathrm{M}-\mathrm{EDTA}$, and $10^{-6} \mathrm{M}-\mathrm{L}-\mathrm{m}$ ethionine. The attractant was $1 \mathrm{O}^{-3} \mathrm{M}-\mathrm{L}$-aspartate. The experiments were carried out for $\mathrm{I} h$ at $30^{\circ} \mathrm{C}$. In the complete system $4.0 \times 10^{5}$ and $4.6 \times 10^{5}$ bacteria were found in the capillary for Expts 1 and 2, respectively.

In Expt $\mathrm{I}$, the bacteria were washed in $\mathrm{IO}^{-2} \mathrm{M}$-potassium phosphate, $\mathrm{pH} 7 \cdot 0, \mathrm{IO}^{-4} \mathrm{M}$-EDTA, and $\mathrm{IO}^{-3} \mathrm{M}-\mathrm{MgSO}_{4}$ at $4{ }^{\circ} \mathrm{C}$ as described in Methods. After the last centrifugation, the pellet (about $0 . \mathrm{I} \mathrm{ml}$ ) was resuspended in $10 \mathrm{ml}$ of the appropriate chemotaxis medium. Hence the final concentrations of phosphate buffer and EDTA were about $10^{-4} \mathrm{M}$ and $10^{-6} \mathrm{M}$, respectively, when the chemotaxis medium lacked phosphate buffer or EDTA. In Expt 2 the bacteria were washed in glassdistilled water at $4{ }^{\circ} \mathrm{C}$ and again after the last centrifugation the pellet was resuspended in $10 \mathrm{ml}$ of the appropriate chemotaxis medium. In this case no phosphate buffer or EDTA was present if the chemotaxis medium lacked them. The medium in the capillary and the bacterial suspension was in each case the same except that the capillary contained attractant.

\begin{tabular}{|c|c|c|}
\hline \multirow[b]{2}{*}{ Chemotaxis medium } & \multicolumn{2}{|c|}{$\begin{array}{c}\text { Bacteria in capillary } \\
(\% \text { of response using complete system })\end{array}$} \\
\hline & Experiment I & Experiment 2 \\
\hline Complete system & 100 & 100 \\
\hline - Phosphate buffer & 86 & 17 \\
\hline -EDTA & 99 & 33 \\
\hline - Methionine & 100 & 107 \\
\hline - Phosphate buffer, EDTA, methionine & 107 & I \\
\hline$+10^{-2} \mathrm{M}-$ Glycerol & I3I & 125 \\
\hline
\end{tabular}

is helpful; (iii) concentrations of ions above $0.0 \mathrm{I} \mathrm{M}$ should be avoided since they inhibit motility; (iv) although addition of an energy source stimulates motility, this is not required since these bacteria contain an endogenous energy source (Adler \& Templeton, I967); (v) oxygen is required unless an energy source is added which yields energy anaerobically under the conditions described here, however, the oxygen is not yet used up at the end of one hour; (vi) the medium for growing the bacteria should not contain D-glucose, owing to catabolite repression of flagella synthesis (Adler \& Templeton, 1967; Yokota \& Gots, 1970), and growth should be below $37^{\circ} \mathrm{C}$ since elevated temperatures prevent synthesis of flagella in many strains of enteric bacteria (Adler \& Templeton, 1967).

Effect of growth conditions on chemotaxis. Growth conditions leading to optimal motility should be used (see Adler \& Templeton, 1967). In addition, as certain taxes are inducible (Adler, 1969), the growth medium should in those cases include an inducer. Examples of inducible taxes are those to galactose, maltose and ribose. Glucose, aspartate and serine taxes appear to be constitutive (Adler, 1969; unpublished data).

The effect of stage of growth on chemotaxis was studied. Bacteria grown in glycerol-salts medium were harvested at $0 \cdot 9, \mathrm{I} \cdot 8,3 \cdot 6,7 \cdot 8$ and $14 \cdot 3 \times 10^{8}$ bacteria $/ \mathrm{ml}$, the last sample being from the post-exponential phase of growth. The bacteria were washed as described in Methods and then used at a concentration of $6 \times 10^{7} / \mathrm{ml}$, the responses to $10^{-3} \mathrm{M}$ aspartate after $\mathrm{I} h$ at $30^{\circ} \mathrm{C}$ were $3 \cdot 7,2 \cdot 9,3 \cdot 0, \mathrm{I} \cdot 4$ and $0.64 \times 10^{5}$ bacteria, respectively. Thus bacteria should be harvested in early exponential phase for the best chemotaxis. Bacteria in late exponential phase or stationary phase showed reduced motility, as judged by microscopic examination.

Requirements of a wash medium. Bacteria were washed free of the growth medium to remove any attractants or repellents, to allow a simple, defined chemotaxis medium and to reduce the high ionic strength of the growth medium which would be inhibitory to motility.

Each of the components of the 'usual wash medium' ( $\mathrm{IO}^{-2} \mathrm{M}$-potassium phosphate, 


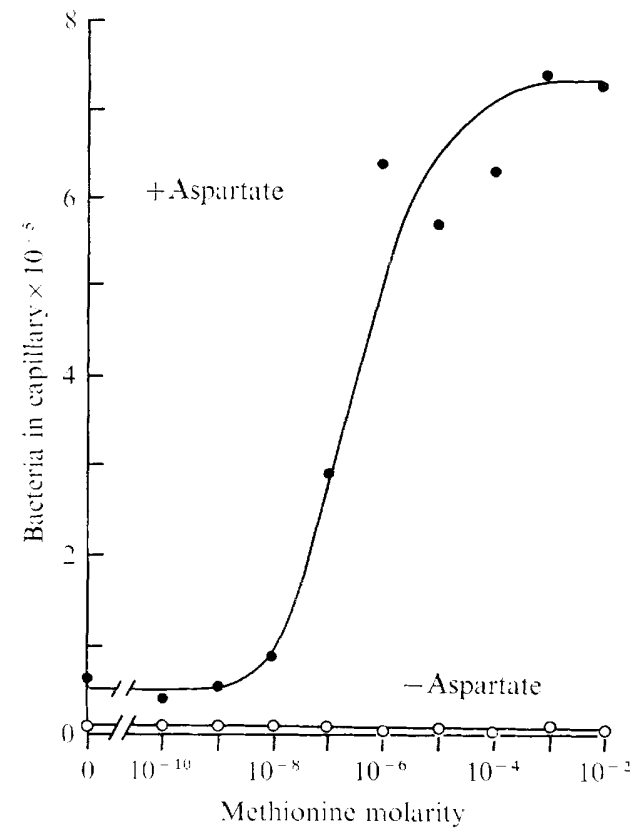

Fig. 6

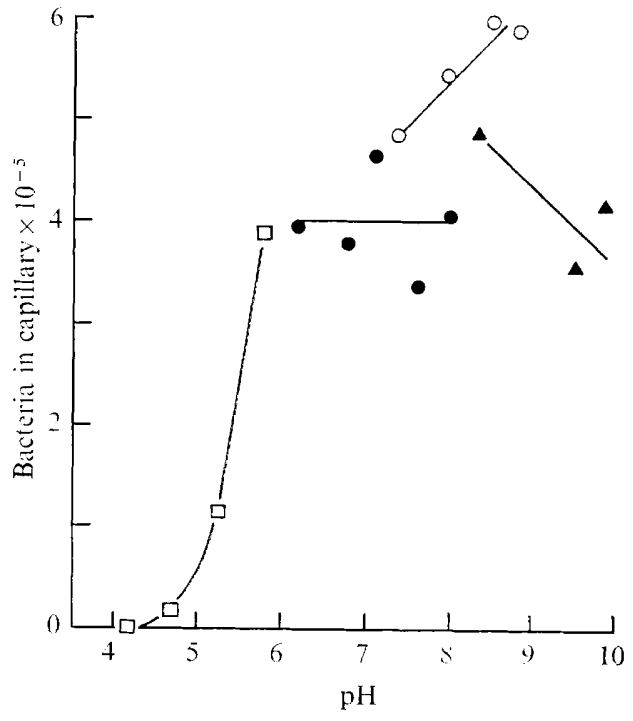

Fig. 7

Fig. 6. Effect of methionine on chemotaxis toward aspartate by a methionine auxotroph, Escherichia coli strain 2-46. L-Methionine was present in both the capillary and bacterial suspension, at the concentration indicated on the abscissa. L-Aspartate, when present (top curve), was in the capillary at $10^{-3} \mathrm{M}$. The bacteria were washed an extra time to remove residual methionine from the growth medium. The experiment was carried out at $30{ }^{\circ} \mathrm{C}$ for $\mathrm{I} h$.

Fig. 7. Effect of $\mathrm{pH}$ on aspartate taxis. Buffers (०.0 I M) used: $\square-[]$, potassium citrate; potassium phosphate; $\mathrm{O}_{-}-\mathrm{O}$, tris hydrochloride; $\mathbf{\Delta}-\mathbf{\Delta}$, potassium $\beta$-alanine. L-Aspartate was present in the capillary at $10^{-3} \mathrm{M}$. The experiment was carried out at $30^{\circ} \mathrm{C}$ for $\mathrm{I} \mathrm{h}$. Final pH values are plotted; initial and final $\mathrm{pH}$ values generally agreed within $0.15 \mathrm{pH}$ units. The bacteria in all cases had been grown at $\mathrm{pH} 7$. In the absence of L-aspartate, the number of bacteria in the capillary at $\mathrm{I} h$ is typically $5-10 \times 10^{3}$ in potassium phosphate buffer, $\mathrm{pH} 7 \cdot 0$.

$\mathrm{pH} 7 \cdot 0, \mathrm{IO}^{-4} \mathrm{M}$-EDTA and $\mathrm{IO}^{-3} \mathrm{M}-\mathrm{MgSO}_{4}$ ) was tried singly and in various combinations, and water (glass-distilled) was also tried. The yield of viable bacteria after washing was the same in all cases. Chemotaxis toward $\mathrm{IO}^{-3} \mathrm{M}$-aspartate and motility, estimated microscopically, showed that EDTA was essential in the wash medium for preparing motile cells (though it could be added after washing to restore motility). Potassium phosphate was not needed for motility, but does have an effect on chemotaxis (see below). $\mathrm{MgSO}_{4}$ was not required either for motility or chemotaxis. On this basis a wash medium containing $1 \mathrm{O}^{-2} \mathrm{M}$-potassium phosphate, $\mathrm{pH} 7 \cdot 0$, and $\mathrm{IO}^{-4} \mathrm{M}$-EDTA is recommended.

Requirements of a chemotaxis medium. Bacteria washed in the usual wash medium did not require added EDTA or potassium phosphate buffer for chemotaxis (Table I, Expt I). Apparently enough of these two reagents was carried over from the wash medium to satisfy these requirements (see legend to Table I). However, bacteria washed in water clearly required the addition of EDTA and potassium phosphate for optimum chemotaxis (Table I, Expt 2). The EDTA was needed to restore motility to such cells. The potassium phosphate $\left(\mathrm{IO}^{-2} \mathrm{M}\right)$ could be replaced by an equal concentration of $\mathrm{KCl}$ or, half as effectively, $\mathrm{NaCl}$. Motility, judged by microscopic examination, was excellent without these additions. This 


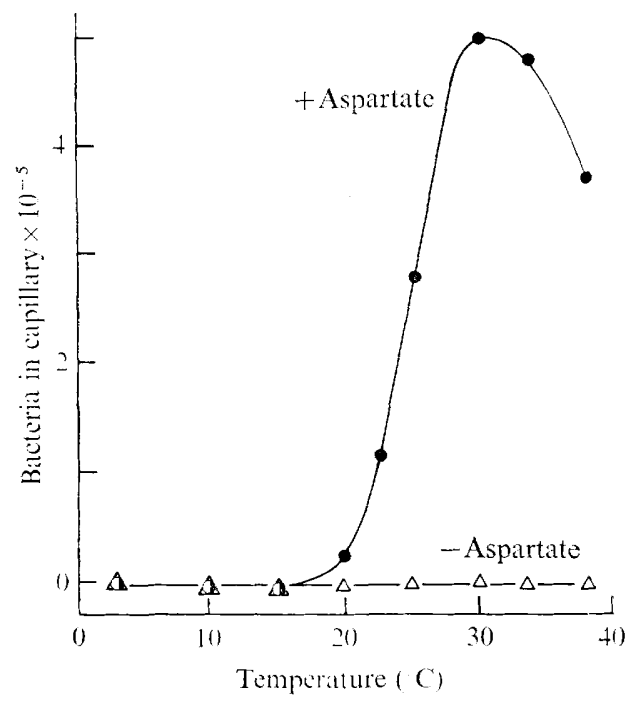

Fig. 8. Effect of temperature. The number of bacteria that had accumulated in the capillary at $\mathrm{I} h$ is plotted as a function of temperature. $\mathrm{L}$-Aspartate, when present (top curve), was at $1 \mathrm{O}^{-3} \mathrm{M}$. Above $25^{\circ} \mathrm{C}$ the temperature was maintained with a Fisher slide warmer, and below $25^{\circ} \mathrm{C}$ with a New Brunswick Psycrotherm incubator. The bacteria in all cases had been grown at $35^{\circ} \mathrm{C}$.

stimulation of chemotaxis by $\mathrm{K}^{+}$or $\mathrm{Na}^{+}$salts is presently under investigation. Divalent cations appear not to be involved extracellularly, since the chelators EDTA or EGTA (ethyleneglycol-bis(aminoethyl)tetraacetate) allowed good motility and chemotaxis even at $\mathrm{IO}^{-2} \mathrm{M}$.

L-Methionine is essential for chemotaxis in strains of Escherichia coli that cannot synthesize it, although the bacteria are fully motile without it (Adler \& Dahl, I967; Fig. 6). At least $\mathrm{IO}^{-6} \mathrm{M}$ is needed when tested under the assay conditions used here (Fig. 6). For bacteria that can synthesize methionine, its addition does not stimulate chemotaxis (Table I); however, if the bacteria are grown in the presence of methionine, which presumably represses methionine synthesis, the addition of methionine can stimulate chemotaxis up to a few-fold. The role of methionine in chemotaxis is unknown, and is currently under study.

The addition of an energy source, such as glycerol, stimulates chemotaxis (Table I) and motility (Adler \& Templeton, 1967); however it is not essential, because of the endogenous energy source.

Aspartate taxis has a broad optimum between pH 6 and 9.5 (Fig. 7). The reduction in taxis below pH 6 reflects a corresponding reduction in motility, as judged by microscopic observation; at $\mathrm{pH}_{4}$ the bacteria were not motile (though they were viable). Motility was

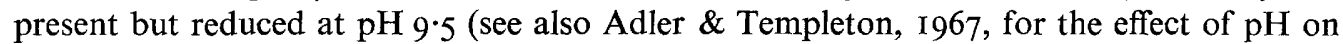
motility). For glucose taxis the curve is similar to that for aspartate except for a sharp decline above $\mathrm{pH} 9$, resulting in $5 \%$ of maximum activity at $\mathrm{pH}$ io. The effect of $\mathrm{pH}$ is not the same for all attractants as different chemicals are detected by different chemoreceptors (Adler, 1969) and each chemoreceptor may have its own $\mathrm{pH}$ optimum. In addition, in the case of ionizable attractants only certain ionic species may be active.

The conditions elucidated here allow chemotaxis to be studied in the absence of growth: sources of energy, carbon, nitrogen, sulphur, and essential growth factors other than methionine can be omitted from the assay.

Effect of temperature. Chemotaxis is dependent upon temperature (Fig. 8). There was no 
detectable chemotaxis at or below $15{ }^{\circ} \mathrm{C}$ and raising the temperature from $20{ }^{\circ} \mathrm{C}$ to $30{ }^{\circ} \mathrm{C}$ resulted in a 20 -fold increase in the number of bacteria attracted. From an Arrhenius plot, i.e. the logarithm of the chemotactic response per hour plotted against the reciprocal of the absolute temperature, the apparent activation energy, or $\mu$, is found to be roughly 80000 calories/mole.

The basis for this unusual temperature dependence of chemotaxis is unknown. Transport and metabolism of the attractant are not responsible, since the same temperature dependence as shown for aspartate was also obtained for taxis toward $\alpha$-methylaspartate, a nonmetabolizable analogue of aspartate, or toward galactose by strain $20 \mathrm{SOK}^{-}$, which is blocked in both the transport and metabolism of that sugar. Motility itself has a lesser dependence on temperature than does chemotaxis. Although not evident from Fig. 8 because of the scale used, motility, indicated by accumulation in a capillary lacking attractant, occurs below $15{ }^{\circ} \mathrm{C}$ and increases only two- to threefold between $20{ }^{\circ} \mathrm{C}$ and $30{ }^{\circ} \mathrm{C}$ (Fig. 8 ; Adler \& Templeton, 1967).

Transport (though not involved in chemotaxis, see Adler, 1969) is another process that is highly dependent upon temperature (Koch, 1964). There is a transition temperature at I 5 to $20^{\circ} \mathrm{C}$ for the transport of $\beta$-galactosides by wild-type Escherichia coli grown under conditions similar to those used here (C. F. Fox, personal communication), likely due to a transition to a liquid-like state of the lipids in the cytoplasmic membrane (Overath, Schairer \& Stoffel, 1970). Since taxis occurs only above $15{ }^{\circ} \mathrm{C}$, this suggests that lipids in their fluid state, and probably membranes, may play a crucial role in chemotaxis.

In view of the temperature-dependence of chemotaxis, the temperature must be accurately controlled if reproducibility is to be obtained.

\section{DISCUSSION}

The major advantage of this method for assaying bacterial chemotaxis is that it provides reproducible quantitation of the phenomenon. Other advantages are that the method is simple and sensitive. Further, chemicals do not have to be metabolized in order to be attractants. The method should be applicable as well to other cells or small organisms.

Disadvantages of the method are that the shape of the gradient cannot be varied by the experimenter (except see modification below) and, since the gradient is formed by diffusion, the shape of the gradient and the area occupied by the gradient are not constant with time. Also, the gradient is affected by metabolism of the attractant by the bacteria, although this effect can be minimized by working with a low concentration of bacteria or by using nonmetabolizable attractants.

While the method cannot be used to measure the rate of migration of organisms as a function of gradient shape, it is suitable for the following purposes: surveying chemicals to find attractants; determining threshold, saturating and optimum concentrations of attractants; and comparing chemotaxis mutants with wild-type organisms. In a modification (Mesibov, Ordal \& Adler, I973) attractant is put into the bacterial suspension at various concentrations, and the concentration of attractant in each capillary is a constant multiple of this (for example tenfold higher). This sets up gradients whose concentrations at the upper and lower limits are always the same fold apart, so the shape of the gradient should be similar in each case.

Alternative methods for studying positive chemotaxis exist. Pfeffer's original method for studying chemotaxis (I884, I888) is the basis for the present assay and is essentially identical to ours, except that in his method only microscopic observations are made and therefore 
it only provided estimates of the size of the accumulation at the mouth of, and inside, the capillary. A second method is to observe and measure the speed of moving bands of bacteria in a tube, or rings of bacteria in a plate containing attractant (Adler, I966, and references cited there to earlier work). The bands or rings are the result of chemotaxis in a gradient produced by bacterial utilization of the attractant. An advantage of this method is that chemotaxis is visible to the naked eye. A major disadvantage is that the experimenter relies on the bacteria to create the gradient; chemicals that are not utilized cannot be tested as attractants, unlike in the present method. The speed of the bands or rings can be easily measured, but this is more an indication of the rate of use of the chemical than an assay of chemotaxis. Recently, Dahlquist, Lovely \& Koshland (1972) have described a quantitative assay for chemotaxis which consists of determining the distribution of bacteria in defined gradients by measuring scattering of a laser beam by the bacteria. The method allows the experimenter to vary the shape of the gradient, and the gradient remains fairly constant over the time used.

Chemotaxis operates over a limited range of concentrations, the 'response range' (Mesibov, Ordal \& Alder, 1973). At the low extreme is the 'threshold concentration', the lowest concentration of attractant in the capillary that gives a detectable response. At the high extreme is the 'saturating concentration', the attractant concentration in the bacterial suspension above which the bacteria cannot detect a still higher concentration in the capillary. The operating range is different for different attractants. For aspartate it is between $3 \times 10^{-8} \mathrm{M}$ and $\mathrm{IO}^{-1} \mathrm{M}$, for galactose between $\mathrm{IO}^{-8} \mathrm{M}$ and $3 \times 10^{-6} \mathrm{M}$ (threshold and saturation, respectively).

The lag period before chemotaxis began (Fig. 2) is considered to be the time it takes to reduce the concentration of attractant at the mouth of the capillary to just below the saturating concentration. This reduction is brought about by two factors, utilization of attractant by the bacteria in the case of metabolizable attractants, and diffusion of the attractant. While few bacteria enter the capillary during the lag period, a cloud of bacteria does form away from the mouth of the capillary wherever the attractant is present at concentrations that are effective for chemotaxis, i.e. between threshold and saturation. The higher the concentration of attractant in the capillary, of course, the longer the lag period for entry will be; also, the lower the saturating concentration, the longer the lag period. Thus for $\mathrm{IO}^{-1}$ and $\mathrm{IO}^{-2} \mathrm{M}$-aspartate the lag was $\mathrm{IO}$ and $6 \mathrm{~min}$, respectively (Fig. 2), while for $\mathrm{IO}^{-1}$ and $\mathrm{IO}^{-2} \mathrm{M}$-galactose the lag was 60 and $\mathrm{IO}$ min, respectively, in the case of wild-type Escherichia coli (data not shown). The effect of utilization of attractant on the lag period is illustrated by the fact that for $\mathrm{IO}^{-1}, \mathrm{IO}^{-2}$, or $\mathrm{IO}^{-3} \mathrm{M}$-galactose the lag was greater than $90 \mathrm{~min}$ in the case of Escherichia coli $20 \mathrm{SOK}^{-}$, the strain that is blocked in the transport and metabolism of galactose (data not shown). When the upper limit of the gradient of attractant has been reduced to below the threshold value, by utilization and/or diffusion, no further response can occur. This would explain the plateau values shown for $\mathrm{IO}^{-5}$ and $1 \mathrm{IO}^{-4} \mathrm{M}-$ aspartate in Fig. 2.

The reason for entry occurring at a more or less constant rate (i.e. for the more or less straight line portions of Fig. 2) is not clear. Perhaps the capillary is 'fed' by the cloud of bacteria that has formed outside the mouth of the capillary, and entry into the capillary is limited by the size of the orifice and the motility of the bacteria. The denser the cloud, the greater the rate of entry; thus aspartate produces denser clouds (presumably because it has a broader response range) than galactose and also higher rates of entry $\left(8 \times 10^{5}\right.$ bacteria/h and $\mathrm{I} \times 10^{5} / \mathrm{h}$, respectively).

The decline of the concentration-response curve at high concentrations of attractant 
(Fig. 3) simply reflects the longer lag periods found for high concentrations. Thus it does"not really represent an inhibition of chemotaxis, though an additional reason for it in the case of ionic attractants is that the high ionic strength, such as is present in $10^{-1} \mathrm{M}$-aspartate, inhibits motility (Adler \& Templeton, 1967). A further possibility might be negative chemotaxis for high concentrations. However, we have found no repulsion by $\mathrm{IO}^{-1} \mathrm{M}$-aspartate or by $\mathrm{IO}^{-1} \mathrm{M}$ galactose (W. W. Tso \& J. Adler, unpublished results).

The procedure described in the present report may also provide an assay for motility if attractant is omitted from the capillary; see, for example, bottom curves of Fig. 2, 4, 6 and 8. In this case, the capillaries and the beakers used for holding the solution for filling the capillaries must be kept scrupulously clean and free of attractants, else the accumulation in the capillaries is variable. Also, an oxygen gradient might attract the bacteria into the capillary, or a repellent in the bacterial suspension might force them into the capillary, though use of low cell concentrations would minimize this. Alternative methods for measuring motility are reviewed in Adler \& Templeton (1967); to this list should be added measuring the lengths of tracks recorded on film (Dryl, 1958; Vaituzis \& Doetsch, 1969), and using a tracking microscope (Berg, 197I).

We have recently developed an assay for negative chemotaxis by a modification of the present method (Tso \& Adler, in preparation). A repellent is put into the bacterial suspension but not into the capillary. One then measures the number of bacteria that have gone into the capillary for 'refuge'.

Various people have made contributions that led to the development of this assay into its present form, particularly W. Pfeffer, M. M. Dahl, R. E. Mesibov, G. W. Ordal, and R. W. Reader. I thank Mrs Dahl for carrying out most of the experiments described here, and Dr H. C. Berg for the numbers in Fig. 5.

This investigation was supported by Public Health Service Grant Alo8746 from the National Institute of Allergy and Infectious Diseases.

\section{REFERENCES}

AdLER, J. (1966). Chemotaxis in bacteria. Science, New York $\mathbf{5 3 3}, 708-716$.

AdLer, J. (1969). Chemoreceptors in bacteria. Science, New York 166, I 588-1 597.

AdLer, J. \& DAHL, M. M. (I967). A method for measuring the motility of bacteria and for comparing random and non-random motility. Journal of General Microbiology 46, I6I-I 73.

AdLer, J. \& Templeton, B. (1967). The effect of environmental conditions on the motility of Escherichia coli. Journal of General Microbiology 46, I75-184.

BERG, H. C. (I97I). How to track bacteria. Review of Scientific Instruments 42, 868-87I.

BerG, H. C. \& Brown, D. A. (1972). Chemotaxis in Escherichia coli: analysis by three-dimensional tracking. Nature, London (in the press).

Dahlquist, F. W., Lovely, P. \& Koshland, D. E. Jun. (1972). Quantitative analysis of bacterial migration in chemotaxis. Nature New Biology, London 236, $120-123$.

DRYL, S. (1958). Photographic registration of movement of protozoa. Bulletin de l'Academie polonaise des sciences. Serie des Sciences biologiques 6, 429-430.

Futrelle, R. P. \& Berg, H. C. (1972). Specification of gradients used for studies of chemotaxis. Nature, London (in the press).

Hazelbauer, G. L., Mesibov, R. E. \& Adler, J. (1969). Escherichia coli mutants defective in chemotaxi toward specific chemicals. Proceedings of the National Academy of Sciences of the United States of America 64, I 300-I307.

Kaiser, A. D. \& Hogness, D. S. (1960). The transformation of Escherichia coli with deoxyribonucleic acid isolated from the bacteriophage $\lambda \mathrm{dg}$. Journal of Molecular Biology 2, 392-4 5.

Косн, A. L. (1964). The role of permease in transport. Biochimica et biophysica acta 79, 177-200. 
Mesibov, R. (1970). Ph.D. Thesis, University of Wisconsin, Madison, U.S.A.

Mesibov, R., ORDAL, G. W. \& ADLER, J. (I973). The range of attractant concentration for bacterial chemotaxis and the threshold and size of response over this range: Weber law and related phenomena. Journal of General Physiology (in the press).

OVerath, P., Schairer, H. U. \& StOFFel, W. (I970). Correlation of in vivo and in vitro phase transitions of membrane lipids in Escherichia coli. Proceedings of the National Academy of Sciences of the United States of America 67, 606-6I2.

PFefFER, W. (I 884). Locomotorische Richtungsbewegungen durch Chemische Reize. Untersuchungen aus dem Botanischen Institut in Tuibingen I, 363-482.

PfefFER, W. (I888). Über Chemotaktische Bewegungen von Bacterien, Flagellaten, und Volvocineen. Untersuchungen aus dem Botanischen Institut in Tübingen 2, 582-661.

VaITUZIS, Z. \& DoETSCH, R. N. (I969). Motility tracks: technique for quantitative study of bacterial movement. Applied Microbiology I7, 584-588.

YокотА, T. \& Gots, J. S. (1970). Requirement of adenosine $3^{\prime} 5^{\prime}$-cyclic phosphate for flagella formation in Escherichia coli and Salmonella typhimurium. Journal of Bacteriology 103, 513-516. 